\title{
Monitoring for seismological and geochemical groundwater effects of high-volume pumping of natural gas at the Stenlille underground gas storage facility, Denmark
}

\author{
Trine Dahl-Jensen $^{1 *} \odot$, Rasmus Jakobsen ${ }^{1} \odot$, Tina Bundgaard Bech ${ }^{1} \odot$, Carsten Møller Nielsen ${ }^{1} \oplus$,

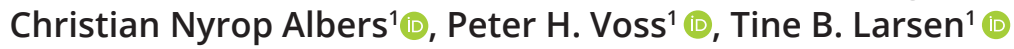 \\ ${ }^{1}$ Geological Survey of Denmark and Greenland (GEUS), Copenhagen, Denmark
}

\begin{abstract}
The large natural gas storage facility at Stenlille, Denmark, has been monitored to investigate the effect of pumping large amounts of gas into the subsurface. Here, we present a new dataset of microseismicity at Stenlille since 2018. We compare these data with methane in groundwater, which has been monitored since gas storage was established in 1989. Further, we conducted a controlled 172 day microcosm experiment of methane oxidation on an isolated microbial community under both aerobic and anaerobic conditions. For this experiment, water was filtered from a well at Stenlille with elevated levels of thermogenic methane and ethane. No microseismic activity was detected in the gas storage area above an estimated detection level of ML 0.0 for the established network. The long-term monitoring for methane in groundwater has still only detected one leak, in 1995, related to a technical problem during injection. The microcosm experiment revealed that oxidation of methane occurred only under aerobic conditions during the experiment, as compared to anaerobic conditions, even though the filtered water was anoxic.
\end{abstract}

\section{Introduction}

Storage of $\mathrm{CO}_{2}$ in the subsurface as a means of reducing $\mathrm{CO}_{2}$ in the atmosphere receives great international interest. Therefore, there is a need for knowledge about how the subsurface behaves when large volumes of gas are pumped into reservoirs accompanied by potential contamination of groundwater aquifers. In Denmark, the primary onshore interest focusses on sandstone reservoirs, with the Gassum Formation as a prime candidate (Hamberg \& Nielsen 2000). The Stenlille underground gas storage facility (Fig. 1a) provides an opportunity to monitor the effects of large-volume pumping; while the gas pumped is natural gas and not $\mathrm{CO}_{2}$, the volume pumped is large and can provide information about the effects of pumping activity on both groundwater geochemistry and microseismic activity.

Leakage is also important to monitor because groundwater aquifers are sensitive to changes (Datry et al. 2004), and therefore increases in methane as well as trace concentrations of other alkanes may alter the groundwater ecosystem. Groundwater aquifers are complex ecosystems that are of critical importance for geochemical cycles (Griebler \& Lueders 2009). Therefore, it has been important to monitor for hydrocarbons in the shallow groundwater

\author{
*Correspondence: $t d j @ g e u s . d k$ \\ Received: 08 Sep 2020 \\ Accepted: 16 Feb 2021 \\ Published: 22 Mar 2021 \\ Keywords: $\mathrm{CO}_{2}$ storage, carbon capture, \\ geochemical monitoring, induced \\ earthquakes, natural gas storage

\section{Abbreviations:} \\ GC-FID: Gas Chromatography Flame \\ Ionization Detector \\ ML: Local magnitude \\ $\mathrm{Mb}$ : Body wave magnitude
}

GEUS Bulletin is an open access, peerreviewed journal published by the Geological Survey of Denmark and Greenland (GEUS). This article is distributed under a CC-BY 4.0 licence, permitting free redistribution, and reproduction for any purpose, even commercial, provided proper citation of the original work. Author(s) retain copyright.

Edited by: Stefanie Lode (GEUS)

Reviewed by: Aaron Cahill (Heriot-Watt University, UK) and one anonymous reviewer

Funding: See page 7

Competing interests: None declared

Additional files: See page 7 
because of the underground gas storage, and thereby detect possible impacts on this environment.

Here, we present a new dataset of microseismicity at Stenlille since 2018 and compare these data with methane in groundwater, which has been monitored since gas storage was established in 1989. Further, we report on a controlled 172 day microcosm experiment of methane oxidation on an isolated microbial community under both aerobic and anaerobic conditions.

\section{Stenlille underground gas storage facility}

The Stenlille underground gas storage facility is located $70 \mathrm{~km}$ south-west of Copenhagen, operated by Gas Storage Denmark A/S (Fig. 1a). It was established in 1989 to buffer the supply of gas from the North Sea and has since been re-developed to increase storage capacity. Today, a total of 20 deep wells operate at the facility. Fourteen wells are deployed for injection and withdrawal of gas and six wells are used for observational purposes. Most observation wells are located in the periphery of the site (Fig. 1b; Laier \& Øbro 2009).

The storage at Stenlille is an anticlinal structure shaped by salt tectonics. A vertical closure of c. $35 \mathrm{~m}$ covers an area of $14 \mathrm{~km}^{2}$ (Fig. 1c). The reservoir is formed in the Upper Triassic - Lower Jurassic Gassum Sandstone Formation, where gas is stored by displacing formation water. The top Gassum surface is located 1500-1600 m below ground level. The Gassum Formation consists of cyclically interbedded sandstone and marine mudstone deposited in a changing depositional environment (Hamberg \& Nielsen 2000). The formation has excellent reservoir properties due to the overlying $300 \mathrm{~m}$ thick Lower Jurassic Fjerritslev formation. It consists of claystone and hence serves as a caprock for the sandstone reservoir.

The total estimated storage capacity of the Stenlille structure equals three billion normal cubic metres $\left(\mathrm{Nm}^{3}\right)$, and due to reservoir heterogeneities, gas is stored in several separate zones.

For safety and environmental reasons, the storage operation is monitored carefully. No sign of gas leakage has been observed in a monitoring well located in a sand stringer $15 \mathrm{~m}$ above the gas reservoir (Laier \& $\varnothing$ bro 2009). Other wells are monitored for possible lateral escape of natural gas. A baseline study of naturally occurring hydrocarbons (Laier \& Øbro 2009) performed before the Stenlille facility came into operation indicated the presence of only trace amounts hydrocarbon gases (in the form of biogenic methane) in the subsurface of the Stenlille facility.

The current amount of gas stored is just under $1600 \mathrm{MNm}^{3}$, with an annual injection and extraction of close to $500 \mathrm{MNm}^{3}$. The pumping rates typically vary between 100 and $250 \mathrm{kNm}^{3} / \mathrm{h}$ but with extraction rates occasionally going up to $400 \mathrm{kNm}^{3} / \mathrm{h}$ (Fig. $1 \mathrm{~d}$ ). The detailed pumping activity for the individual wells for the period summer 2018 to summer 2019 can be seen in supplementary file S1.

\section{Methods}

\section{Seismological monitoring}

During August and September 2018, we established a seismic network for monitoring microseismicity around the Stenlille underground gas storage facility. The network consists of six seismographs placed within $5 \mathrm{~km}$ of the main pumping facility (Fig. 1b). Data for the period 1 October 2018 to 31 March 2020 have been screened for events, using the CONDET code (Havskov et al. 2020). The screening triggers several hundred times on the data. The triggers are very unevenly spaced in time, depending not only on actual seismic events, but also on thunderstorms and noise. A manual screening of the triggered events resulted in 32 locatable seismic events and a large number of acoustic events related to thunderstorms.

\section{Geochemical monitoring}

Monitoring for hydrocarbons has been carried out monthly from 1989 to 1994, followed by quarterly measurements thereafter by the Geological Survey of Denmark and Greenland (GEUS). Shallow groundwater is monitored from private drinking water wells, groundwater wells supplying waterworks in the vicinity of the gas storage and observation wells at Stenlille. The two observation wells, K1 and K2, were established where the risk of leakage was considered highest. Observation well $\mathrm{K} 1$ allows water samples to be taken from melt-water sand at $36 \mathrm{~m}$ depth and at $98 \mathrm{~m}$ in Paleocene calcareous sand (Fig. 2). Observation well K2 was established in 1993 with a screen in the melt-water sand at a depth of 25-39 m (Fig. 2). Groundwater was sampled quarterly in $15 \mathrm{~mL}$ serum bottles with rubber septa and stored at $5^{\circ} \mathrm{C}$ until analysis within two days of sampling. Analysis of C1-C4 hydrocarbons was done by gas chromatography flame ionization detection (GC-FID) on a Shimadzu GC2010 equipped with a capillary column (GS-Gaspro, $60 \mathrm{~m}, 0.32 \mathrm{~mm}$ ) with a detection limit of $2 \mu \mathrm{g} / \mathrm{L}$ for both methane and larger hydrocarbons.

\section{Microcosm experiment}

A total of $2400 \mathrm{~L}$ of groundwater was pumped and filtered over a glass fibre filter with a pore size of $0.3 \mu \mathrm{m}$ and $293 \mathrm{~mm}$ in diameter (Sterlitech, Kent, Washington, USA) using a submersible pump (Grundfos MP1, Grundfos, Bjerrringbro, Denmark). The pump rate was 8-10 L min-1 (September 2019). The filter was stored 

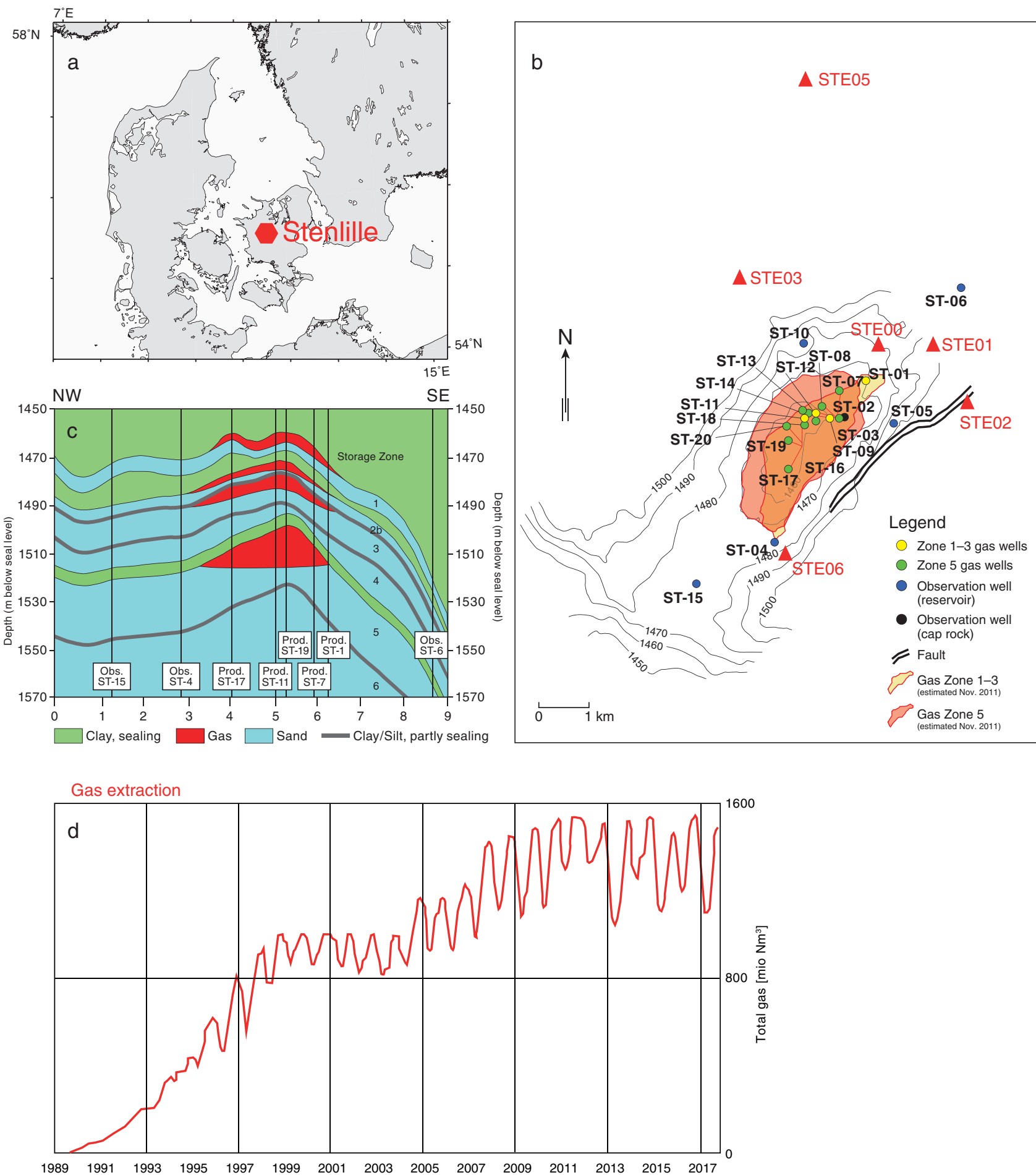

Fig. 1 Location, site details and pumping activity at the Stenlille underground gas storage facility. a: The Stenlille facility is located on Sjælland, Denmark (red hexagon) b: Well locations and extension of the different gas zones at the Stenlille underground gas storage facility. Contour lines indicate depth in metres to the top Gassum Formation. Red triangles indicate the Stenlille seismic network seismographs deployed as part of the SECURe project. Seismographs are within $5 \mathrm{~km}$ of the main pumping station (STE00). ST-01 to -20 are wells and STE01-06 are seismic stations. Modified from Gas Storage Denmark A/S 2018 (Fig. 2.2). c: The cross-section of the Stenlille underground gas storage facility. Prod.: production well. Obs.: observation well. Modified from Gas Storage Denmark A/S 2018 (Fig. 2.1). d: History of pumping activity at Stenlille. Modified from Gas Storage Denmark A/S 2018 (Fig. 3.1). 


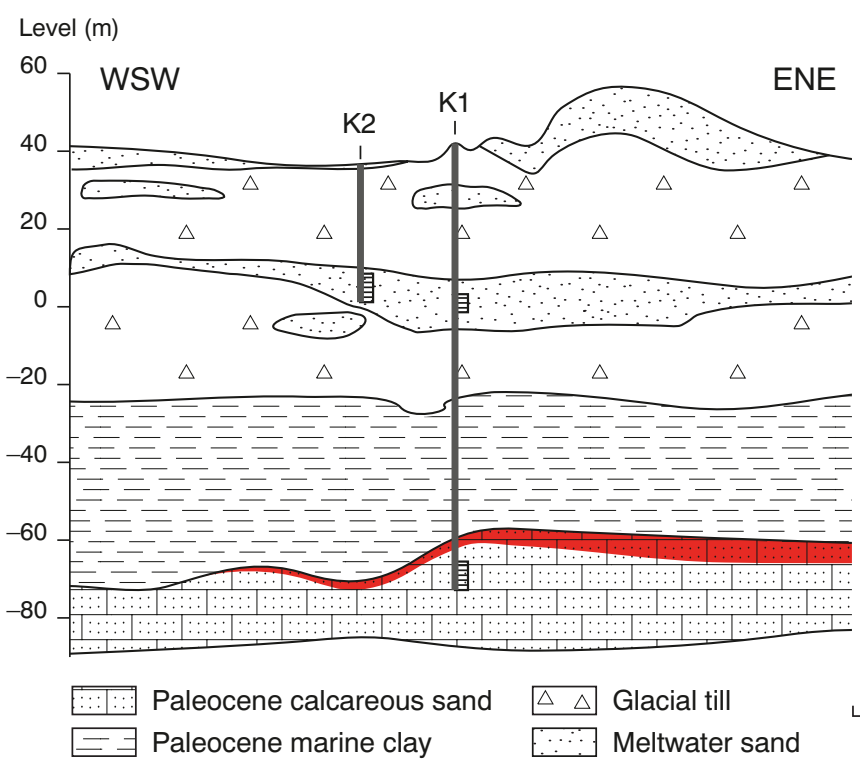

cold after sampling and microcosms were setup within 24 hours. The filter was divided into 24 fragments, and each part was placed in a $583 \mathrm{~mL}$ flask containing $90 \mathrm{~mL}$ of groundwater and $10 \mathrm{~mL}$ of salt solution. The concentrations in each microcosm were $0.62 \mathrm{mM} \mathrm{MgSO} \cdot \cdot 7 \mathrm{H}_{2} \mathrm{O}$, $0.99 \mathrm{mM} \mathrm{KNO}_{3^{\prime}} 0.88 \mathrm{mM} \mathrm{NH}_{4} \mathrm{Cl}, 0.18 \mathrm{mM} \mathrm{NaHCO}{ }_{3^{\prime}} 0.51$ $\mathrm{mM} \mathrm{NaCl}, 0.52 \mathrm{mM} \mathrm{CaCl} \cdot 2 \mathrm{H}_{2} \mathrm{O}, 5.00 \mathrm{mM} \mathrm{CaCO}_{3}$ and $0.50 \mathrm{mM} \mathrm{Fe}(\mathrm{III}) \mathrm{OOH}$. Flasks were crimp sealed with butyl rubber stoppers and flushed with He before a controlled headspace was created comparing (1) untreated control, (2) $\mathrm{CH}_{4}$ and (3) $\mathrm{CH}_{4}$ and $\mathrm{C}_{2} \mathrm{H}_{6}$ under both aerobic and anaerobic conditions. Flasks were incubated in the dark at $10^{\circ} \mathrm{C}$ on a rotational shaker at $75 \mathrm{rpm}$. During incubation, the concentrations of $\mathrm{CH}_{4^{\prime}} \mathrm{C}_{2} \mathrm{H}_{6^{\prime}} \mathrm{O}_{2}$ and $\mathrm{CO}_{2}$ was quantified by GC-FID.

\section{Results and discussion \\ Seismological events}

Of the 32 located events, 20 were previously known (both earthquakes and explosions) and occurred close to Stenlille (Fig. 3) or were large enough and had a frequency content within the range used to trigger on the Stenlille stations alone. Twelve previously unknown and 'spurious events' (events of unknown origin) were found. These were only observed on the Stenlille network along with many similar events, which could not be located. None of the events found are within the Stenlille underground gas storage facility (Fig. 3). The events identified are of a local magnitude (ML) of -0.2 to 2.5. A distant event with body wave magnitude (Mb) 6.7 is observed and two regional events of ML 3.5 and ML 2.8 were also observed. The newly identified spurious events are all smaller than ML 1.0. A full list is provided in supplementary file $\mathrm{S} 2$.
Fig. 2 Geological cross-section of the upper layers of the Stenlille underground gas storage facility. Approximate location and depth of monitoring screens in $\mathbf{K} \mathbf{1}$ and $\mathbf{K} \mathbf{2}$ are shown. The red shading indicates the probable distribution of gas after a leakage event at ST-14 in August 1995. Modified from the work of Laier (2012).

\section{Earthquakes and explosions}

These events, detected by screening the Stenlille network, were all previously located by the routine monitoring of the Danish seismic service. The fact that these events were also detected by independent screening of the Stenlille seismic network confirms the fact that the network is capable of detecting such events (Fig. 3).

\section{Spurious events}

These events all have magnitudes smaller than ML 1 (Fig. 3) - most are much smaller and all have similar signals, with strangely low frequencies in the range of $10 \mathrm{~Hz}$. This is much lower than expected for such small events. We do not know the cause of these events and their locations have an uncertainty of up to tens of kilometres. Nonetheless, due to the difference in $\mathrm{P}$ and $\mathrm{S}$ wave arrival times (which relates to the distance from the station to the event; data not shown) we are convinced that they do not originate within the area of the Stenlille underground gas storage facility.

\section{Correlation with pumping}

We have detailed information on the pumping activity at the Stenlille underground gas storage facility (see supplementary file S1). However, we observe no seismic events in the immediate vicinity of the Stenlille facility, and so it is not possible to correlate events at Stenlille with pumping activity.

\section{Detection level}

In order to determine the detection level within the area covered by the Stenlille facility we have used 10 natural earthquakes detected by the Stenlille network. 


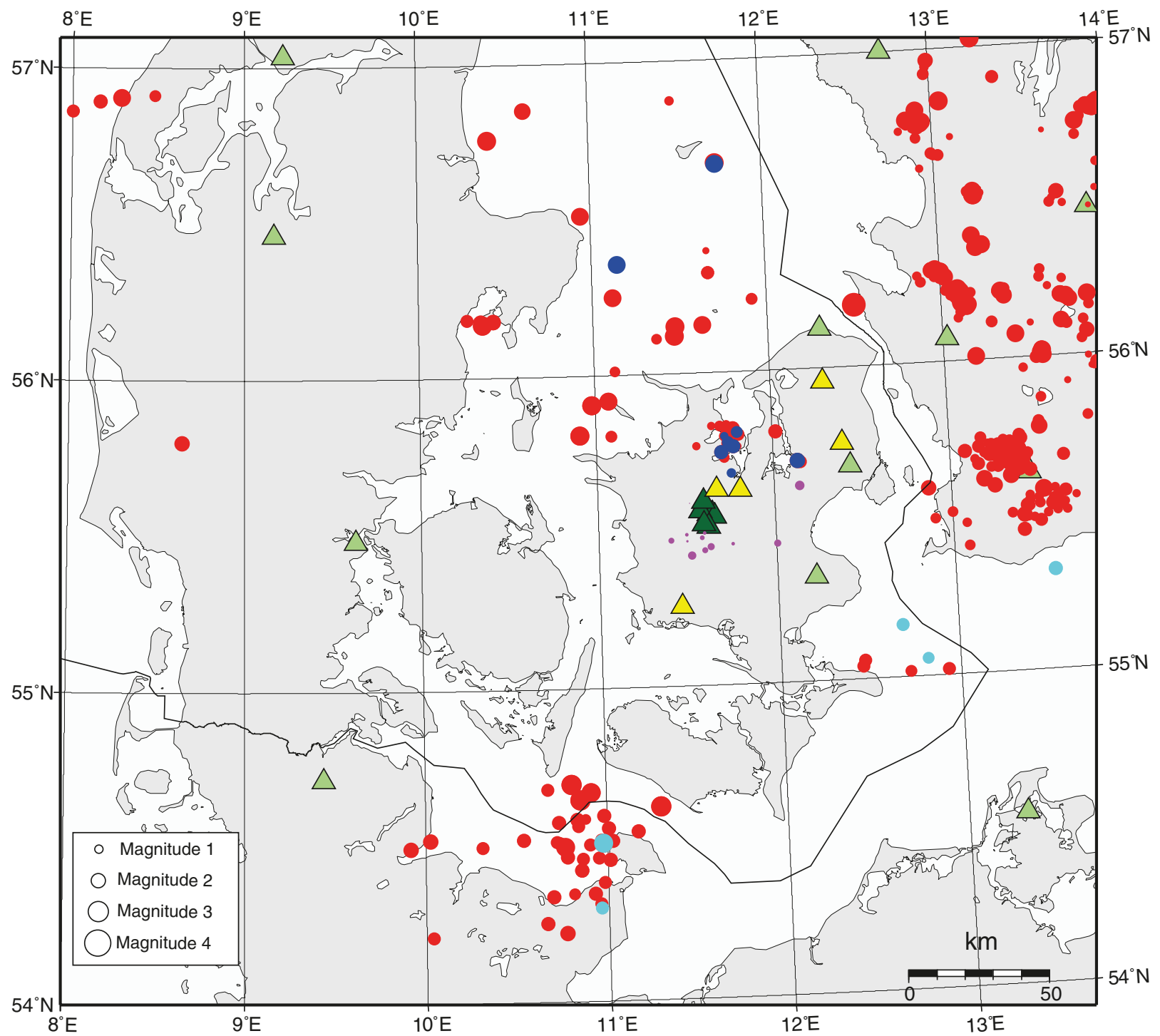

Fig. 3 Seismological events detected by screening data from the Stenlille seismic network. Blue: earthquakes. Light blue: explosions or presumed explosions. Lilac: spurious events. Red: earthquakes and explosions found by the Danish Seismological Service in the period October 2018 to March 2020. Triangles are seismological stations. Dark green: the Stenlille network. Yellow: Raspberry Shake stations. Light green: permanent stations in national networks.

Table 1 Observed local magnitude (ML) around Stenlille Natural Gas Storage Facility

\begin{tabular}{lcccccccccc}
\hline Distance $(\mathbf{k m})$ & $\mathbf{1}$ & $\mathbf{2}$ & $\mathbf{3}$ & $\mathbf{4}$ & $\mathbf{5}$ & $\mathbf{6}$ & $\mathbf{7}$ & $\mathbf{8}$ & $\mathbf{9}$ & $\mathbf{1 0}$ \\
\hline Average observed ML (no units) & -1.2 & -0.7 & -0.4 & -0.2 & 0.0 & 0.1 & 0.2 & 0.3 & 0.4 & 0.4 \\
\hline
\end{tabular}

The equation for calculating the $\mathrm{ML}$ for earthquakes in Denmark is:

$\mathrm{ML}=0.925 \times \log 10(\mathrm{~A})+1.61 \log 10(\Delta)-2.38$

where $A$ is the maximum amplitude of the $S$ and surface wave arrival train in $\mathrm{nm}$ and $\Delta$ is the distance in $\mathrm{km}$ (Gregersen 1999). Using the amplitude actually observed at each of the Stenlillle stations for each of the 10 natural earthquakes and calculating what ML would be at distances covering the Stenlille gas storage area, we obtain a series of estimates at which magnitudes it would be possible to see if the events occurred within the Stenlille gas storage facility. The complete set of calculations are provided in supplementary file S3. Average values for all earthquakes and stations are shown in Table 1. We estimate the detection level of the Stenlille seismic network to be at least ML 0.0. Examples of noise analysis can be found in supplementary file S4. 


\section{Why are no events observed at Stenlille?}

The Stenlille network has, through 18 months of monitoring, not registered any seismic events within the Stenlille underground gas storage facility. The detection level is estimated to be at or below ML 0.0, meaning that any missed events are very small.

GEUS has monitored for earthquakes in Denmark for many years, and no earthquake has ever been located at Stenlille, bearing in mind that the detection level for the national monitoring network is higher at ML 2.0 (Dahl-Jensen et al. 2013; Voss et al. 2015). The Stenlille facility has been operational since 1989, pumping up to $500 \mathrm{MNm}^{3}$ of gas in and out (Fig. 1d) and has to our knowledge never received a complaint about shaking.

We do not know the reason for the lack of events, but we can speculate. Of course, events below our detection level could be occurring. It is possible that during the operation of the monitoring network, after almost 30 years of pumping, all stresses have long since been relieved. Possibly events did occur early in the storage facility's life. The stresses in the subsurface, both natural and established by the pumping itself, are too small to trigger earthquakes.

\section{Geochemistry: preliminary results and long- term monitoring}

Prior to operational onset the background concentration in the groundwater aquifers at Stenlille contained only biogenic methane with concentrations $<0.5 \mathrm{mg} / \mathrm{L}$ (Laier \& Øbro 2009). Hence, leaks from the gas storage site are simple to monitor due to low methane background concentrations and the lack of higher hydrocarbons. The injected gas consists of methane (89.5\%), ethane (6.9\%) and propane (2.6\%; Laier \& Øbro 2009); therefore, traces of ethane in groundwater would be a sensitive indicator of gas leakage. The analytical detection limit is c. $2 \mu \mathrm{g} / \mathrm{L}$.

During the 30 years of operation, there has only been one known leakage. In September 1995 there was a leak due to technical problems during gas injection, and even though it was quickly stopped, an estimated $5000 \mathrm{Nm}^{3}$ were lost to geological formations above the
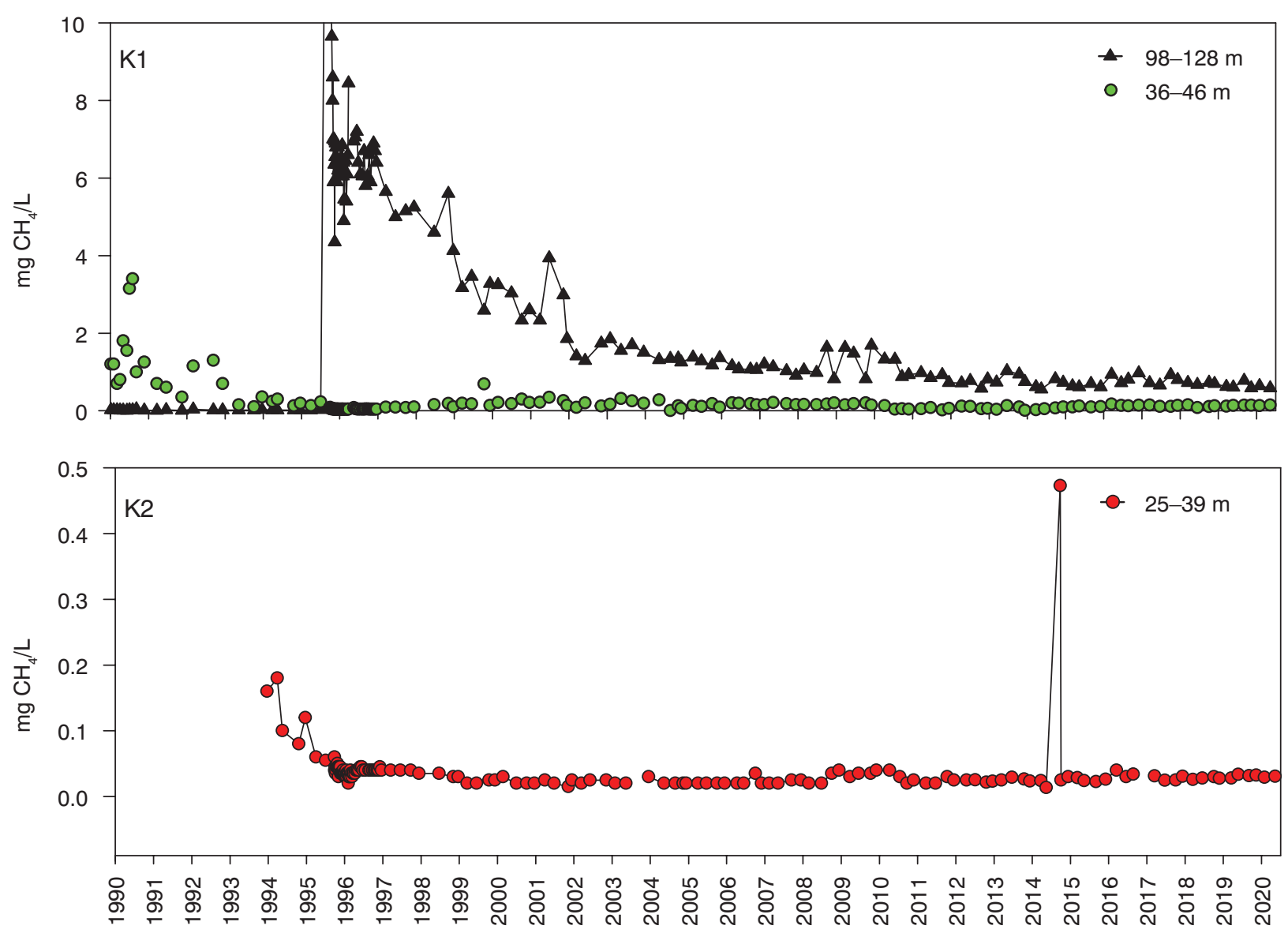

Fig. 4 Methane concentration in groundwater from monitoring wells K1 (91-128 m and 36-46 m depth) and K2 (25-39 m depth). In 1995, methane concentrations reached $27 \mathrm{mg} / \mathrm{L}$ in the deep K1 screen. 
reservoir cap rock. For further details see the work of Laier \& Øbro (2009). This leak has resulted in elevated thermogenic methane and ethane concentrations in the deep K1 monitoring with a decreasing trend since 1995 as shown in Fig. 4.

Methane in groundwater aquifers can have different origins. Thermogenic methane can rise from deeper or shallower hydrocarbon reservoirs into shallow sediment layers and aquifers due to natural gas migration, as observed from contamination in the deep K1 well. Biogenic methane originates from methanogens that produce methane from acetate or hydrogen and $\mathrm{CO}_{2}$ released when other microorganisms ferment organic matter in anoxic subsurface systems (Beeman \& Suflita 1990; Kleikemper et al. 2005). Biogenic methane is detected in the $\mathrm{K} 2$ screen.

During migration, methane can be oxidized by methanothrophic bacteria or archaea. This oxidation may occur aerobically in the presence of oxygen or anaerobically with nitrate, sulphate, and oxidized forms of iron and manganese. Because the energetics of the anaerobic process are severely constrained, the process can take place only through syntrophic cooperation, involving interspecies electron transfer or other interdependencies. Accordingly, anaerobic methane-oxidizing archaea organisms have never been obtained in pure cultures (Knittel \& Boetius 2009).

Even though methane is often detected in groundwater with reducing redox conditions there is limited literature on methane oxidation in groundwater compared to marine and freshwater sediments. Hence, from the thermogenic impacted $\mathrm{K} 1$ well, isolated microbial communities were established in controlled microcosms under both aerobic and anaerobic conditions to compare methane and ethane oxidation at Stenlille. The concentration of methane and ethane were monitored for 172 days. During the incubation study the average methane oxidation rate was $35.97 \mu \mathrm{mol} \mathrm{L}^{-1}$ day $^{-1}$ and $27.99 \mu \mathrm{mol} \mathrm{L}-1$ day $^{-1}$ in a headspace of methane or methane and ethane, respectively. The average ethane oxidation rate was 11.07 $\mu \mathrm{mol} \mathrm{L}{ }^{-1}$ day ${ }^{-1}$. Oxidation of $\mathrm{CH}_{4}$ occurred only under aerobic conditions even though the isolated microbial community was adapted to anaerobic conditions from the $\mathrm{K} 1$ well. Further, the added salt solution contained $\mathrm{NO}_{3}, \mathrm{SO}_{4}$ and $\mathrm{Fe}$ (III) that have been shown to work as an electron acceptor during anaerobic methane oxidation. Lack of methane oxidation under anaerobic conditions has been observed elsewhere (Cahill et al. 2017; Kuloyo et al. 2020).

\section{Implications for future $\mathrm{CO}_{2}$ gas storage sites in Denmark}

We report no seismic events at the Stenlille facility during the monitoring period (October 2018 to May 2020) and no sign of elevated methane concentrations in the shallow groundwater that could be linked to operational activities. Further, if small leaks are occurring from the underground storage there is a natural capacity in the microbial subsurface community to oxidize methane as observed in our microcosm experiments. Based on our results, this oxidation will most likely take place in the transition zone between aerobic and anaerobic conditions, or potentially by an anaerobic community not captured in our experimental setup.

It is important to detect leakage immediately. The seismic method described facilitates an online continuous detection and could be combined with additional geochemical sampling. This could supplement the quarterly monitoring, triggered by registered seismic events of a certain magnitude and location. This does not imply that seismic events necessarily lead to leakage, but it could be an additional tool to increase the likelihood of rapidly detecting a leak.

\section{Acknowledgements}

The authors thank Gas Storage Denmark A/S for hosting a seismic station and providing them with pumping data and methane samples. They are also thankful to the residents in the vicinity of the Stenlille underground gas storage facility who kindly allowed them to place seismic monitoring stations on their properties.

\section{Funding}

This work was carried out as part of the EU project SECURe, funded by the European Union's Horizon 2020 research and innovation program under grant agreement number 764531.

\section{Author contributions}

TDJ: Conceptualization, Formal Analysis, Investigation, Methodology, Resources, Visualization, Writing - original draft, Writing - review \& editing. RJ: Resources, Supervision, Writing - review \& editing. TIB: Data curation, Methodology, Visualization, Writing - original draft, Writing review \& editing. CMN: Conceptualization, Project administration, Writing - original draft, Writing - review \& editing. CAL: Data curation, Investigation, Writing - original draft. PV: Conceptualization, Data curation, Formal Analysis, Investigation, Software, Writing - review \& editing. TBL: Data curation, Formal Analysis, Investigation, Writing review \& editing

\section{Additional files}

Four additional files are available at $h$ ttps://doi.org/10.22008/FK2/T2251F

\section{References}

Beeman, R.E. \& Suflita, J.M. 1990: Environmental factors influencing methanogenesis in a shallow anoxic aquifer: a field and laboratory study. Journal of Industrial Microbiology 5(1), 45-57. https://doi. org/10.1007/BF01569605

Cahill, A.G., Steelman, C.M., Forde, O., Kuloyo, O., Ruff, S.E., Mayer, B., Mayer, K.U., Strous, M., Ryan, M.C. \& Cherry, J.A.J.N.G. 2017: Mobility and persistence of methane in groundwater in a controlled-release field experiment. Nature Geoscience 10(4), 289-294. https://doi. org/10.1038/ngeo2919

Dahl-Jensen, T., Voss, P.H., Larsen, T.B. \& Gregersen, S. 2013: Seismic activity in Denmark: detection level and recent felt earthquakes. Geological Survey of Denmark and Greenland Bulletin 28, 41-44. https:// doi.org/10.34194/geusb.v28.4717

Datry, T., Malard, F. \& Gibert, J. 2004: Dynamics of solutes and dissolved oxygen in shallow urban groundwater below a stormwater 
infiltration basin. Science of the Total Environment 329(1-3), 215229. https://doi.org/10.1016/j.scitotenv.2004.02.022

Gas Storage Denmark A/S. 2018: Stenlille gaslager - Undergrunden Årsrapport 2017 Rep. Unpublished company report for Gas Storage Denmark (in Danish only).

Gregersen, S. 1999: National Survey and Cadastre (KMS), Copenhagen, Denmark. In: EMSC-CSEM Newsletter No 15. European-Mediterranean Seismological Centre.

Griebler, C. \& Lueders, T. 2009: Microbial biodiversity in groundwater ecosystems. Freshwater Biology 54(4), 649-677. https://doi. org/10.1111/j.1365-2427.2008.02013.x

Hamberg, L. \& Nielsen, L.H. 2000: Shingled, sharp-based shoreface sandstones: depositional response to stepwise forced regression in a shallow basin, Upper Triassic Gassum Formation, Denmark. Geological Society, London, Special Publications 172, 69-89. https://doi. org/10.1144/GSL.SP.2000.172.01.04

Havskov, J., Voss, P.H. \& Ottemöller, L. 2020: Seismological Observatory Software: $30 \mathrm{yr}$ of SEISAN. Seismological Research Letters 91(3), 1846-1852. https://doi.org/10.1785/0220190313

Kleikemper, J., Pombo, S.A., Schroth, M.H., Sigler, W.V., Pesaro, M. \& Zeyer, J. 2005: Activity and diversity of methanogens in a petroleum hydrocarbon-contaminated aquifer. Applied and
Environmental Microbiology 71(1), 149-158. https://doi.org/10.1128/ AEM.71.1.149-158.2005

Knittel, K. \& Boetius, A. 2009: Anaerobic oxidation of methane: progress with an unknown process. Annual Review of Microbiology 63(1), 311-334, https://doi.org/10.1146/annurev.micro.61.080706.093130 Kuloyo, O., Ruff, S.E., Cahill, A., Connors, L., Zorz, J.K., Hrabe de Angelis, I., Nightingale, M., Mayer, B. \& Strous, M. 2020: Methane oxidation and methylotroph population dynamics in groundwater mesocosms. Environmental Microbiology 22(4), 1222-1237. https:// doi.org/10.1111/1462-2920.14929

Laier, T. 2012: Results of monitoring groundwater above the natural gas underground storage at Stenlille, Denmark. Geological Survey of Denmark and Greenland Bulletin 26, 45-48. https://doi.org/10.34194/ geusb.v26.4748

Laier, T. \& Øbro, H. 2009: Environmental and safety monitoring of the natural gas underground storage at Stenlille, Denmark. Geological Society, London, Special Publications 313(1), 81-92. https://doi. org/10.1144/SP313.6

Voss, P., Dahl-Jensen, T. \& Larsen, T.B. 2015: Earthquake hazard in Denmark. Unpublished Geological Survey of Denmark and Greenland report, 2015/24, p. 53. Copenhagen: Geological Survey of Denmark and Greenland. 